\title{
PREFACE
}

\section{MODERN SCIENCE ON WHO WE ARE AS FREE AND/OR RELATIONAL BEINGS}

$\mathbf{T}$

HIS BOOK EXAMINES THE INFLUENCE the philosopher René Descartes, the political theorist John Locke, and the biologist Charles Darwin have had on our modern understanding of human beings and human virtue. Written by leading thinkers from a variety of fields, its thirteen chapters reflect on the complex relation between modern science and modern virtue, that is, between a kind of modern thought and a kind of modern action. The volume offers more than just a series of substantive introductions to Descartes', Locke's, and Darwin's respective accounts of who we are and the kind of virtue to which we can aspire, though it does do that. It ultimately invites the reader to think about the ways in which the writings of these three seminal thinkers shaped the democratic and technological world in which we modern human beings live.

The contributors to this volume cover a great deal of ground. Each author learnedly addresses subjects and questions drawn from the diverse disciplines of political science, philosophy, theology, biology, and metaphysics. But let the reader be warned: The authors of these essays are anything but consensual in their analysis. Set side by side and read as a whole, the chapters in this volume carry out an internal debate that mirrors theoretical modernity's ongoing debate about the true nature of human beings and the science of virtue. Authors like Larry Arnhart, Lauren Hall, and to a lesser degree, James Stoner, for example, argue powerfully that Locke's and Darwin's thought is, in principle, amenable to the claims made about human beings and human virtue by classical philosophers such as Aristotle and classical Christian theologians such as Thomas Aquinas. Others, such as Peter Lawler, Marc Guerra, Thomas Hibbs, and Paul Seaton 
make the opposite case, drawing attention to the ways in which Descartes, Locke, and Darwin knowingly and dialectically depart from central teachings of both classical philosophy and classical Christian theology. Readers can judge on their own which side of this argument they find most persuasive. Regardless of which side they fall on, however, I am sure they will walk away having learned something new and having seen a dimension of this debate they had not seen before.

Rather than walk the reader through short and sketchy treatments of the rich chapters that follow, I want to touch on some of the concrete ways in which theoretical or academic debates about the true relationship between science and virtue actually manifest themselves in American society today. After all, whatever differences they had, Descartes, Locke, and Darwin not only agreed (to use Richard Weaver's phrase) that "ideas have consequences," but each intended their ideas about human beings and human virtue to have real, world-changing consequences.

\section{AMERICAN CARTESIANISM TODAY}

One of the more curious features of America's contemporary political landscape is that the most resolute-if frequently unwitting-followers of the seventeenth-century French philosopher René Descartes tend to be libertarians. This is not a new phenomenon, however. Alexis de Tocqueville famously remarked that America is "the one country in the world where the precepts of Descartes are least studied and best followed." Contemporary Cartesian-libertarians are likely to be for gay rights and for property rights and against any claims that treat an individual as part of some greater whole. American Cartesians are typically "non-foundationalists." In their view, the individual's irreducible existence is the bottom line. Recourse to country or to nature or to God to defend the individual's existence only detracts from his singular existence. Worse still, such appeals might result in the individual being slaughtered in the name of some collective, ideological cause that is not his own.

American Cartesians frequently use academically trendy language like "deconstruct" (good) and "privilege" (bad). When analyzing American democracy, they are likely to deconstruct any theory that privileges one person's word over another. Such theorists assert that the democratic individual as democratic individual should resist being absorbed into any social or relational whole, from the family up to the nation. Democratic 
Cartesianism liberates the individual from the authority of priests, poets, philosophers, preachers, politicians, (theoretical) physicists, parents, and the judgment of the Bible's personal God. It also, as the nineteenthcentury democratic theorist Walt Whitman celebrated, inexorably marks the individual's unlimited, indefinite movement away from nature and toward self-creation.

Our Constitution is often read in this Cartesian light. That is not surprising. In many ways, the Constitution lends itself to such a reading. The Constitution treats human beings as wholly free or self-sufficient persons. It does not subsume the individual " $\mathrm{I}$ " into some pre-existing class or category-for example, as part of some religion or race or class or gender. Of course, as a political document the Constitution cannot help but recognize the distinction between citizen and non-citizen. But even this distinction is treated as an artificial construction, that is, not as reflecting some deep statement about who the citizen or non-citizen really is.

The Constitution of 1787 is remarkably silent about a remarkable number of things. It is silent about God, choosing not to employ theology politically. It is also silent about human beings' biological nature. The Constitution, for example, does not recognize the natural division of members of our species into men and women. As it presents them, Americans are free to consent to God's or nature's governance. Of course, by making all of these things subject to the individual's consent, the Constitution quietly saps the authority that earlier theologians and philosophers claimed belonged to God and nature. That sapping, however, is part and parcel with the claims of American Cartesianism. In fact, in some sense it is the very point of American Cartesianism.

The fabulously wealthy cofounder of PayPal, Peter Thiel, offers a good example of this kind of American Cartesianism. In his spirited 2009 essay, titled "The Education of a Libertarian," he writes, "I stand against confiscatory taxes, totalitarian collectives, and the ideology of the inevitability of the death of every individual." Simply put, he proclaims to stand against everything that works against the perpetuation of the authentic liberty of the irreducible "I" that is called Peter Thiel. Thiel is something of a rare bird: He is a Cartesian who may well have read Descartes. At Stanford, the French theorist René Girard taught him about "mimetic desire." From Girard, Thiel would have heard that people usually do not make choices about what they want from an individual perspective. Rather, our choices are usually mediated through and borrowed from other people. Traditionally, 
human beings have thoughtlessly lived in herds. As a result, they have tended to lack genuinely personal or liberated or Cartesian identities. Perhaps it was with these insights in mind that Thiel decided to invest in Facebook.

Thiel seems to think that freedom from the inevitability of death is a precondition for the pursuit of every other human good. Rejecting Socrates' claim that philosophy teaches us to die, Thiel criticizes intellectuals and philosophers who retreat "to tending their small gardens" instead of waging war on "the relentless indifference of the universe" to personal or individual being. For the Cartesian-libertarian, the escape from nature to freedom cannot be imaginary or merely intellectual. It must be real.

\section{AMERICAN DARWINISM TODAY}

Recent years have witnessed the emergence of a growing number of newfangled, Darwin-influenced theorists who publicly insist that their scientific research points in a moderately socially conservative direction. Darwin-friendly theorists ranging from Francis Fukuyama to Jonathan Haidt to the late James Q. Wilson have all argued that by serving his or her family, tribe, and species the social human animal provides a salutary, partial antidote to the self-absorbed and socially apathetic claims of today's dogmatic libertarianism. Their works remind us that our true significance lies in being somewhat self-sacrificing parts of wholes that are greater than ourselves. They also remind us that we human beings are naturally more like gregarious chimps than the solitary and emotionally challenged natural individuals described by Rousseau and mocked on Seinfeld.

Most evolutionary scientists, however, regard conservative social and political thought to be too religious or theological to be deserving of their reputable, scientific support. Yet academically fashionable postures can often be misleading. Take the father of the sociobiology movement, E. O. Wilson, for example. His magisterial The Social Conquest of Earth criticizes Pope Paul VI's encyclical banning the use of artificial contraception for being equal parts dogmatic and unscientific. But Wilson seems to go out of his way to criticize Humanae vitae in part in order to obscure the unfashionable ways in which he actually agrees with the encyclical. According to Wilson, the pope's argument reduces to the claim that God only intended sexual intercourse to be for the purpose of conceiving children. Wilson should have also pointed out that Paul VI thought that natural law 
was on his side as well. As embarrassing as Wilson and other sophisticated scientists like him may find it, Paul VI, from one point of view, also seems to be Darwinian here. After all, his argument is that members of the human species purposely pair, bond, reproduce, and raise their young and so human sex is deformed when it is artificially divorced from those naturally occurring social activities.

Wilson himself notes that natural selection points to a genetically present tension in each member of our species. On the one hand, natural selection produces cooperative social behaviors in human beings. On the other hand, it produces self-serving behaviors in human beings. In Wilson's words, that opposition "renders each of us part saint and part sinner." Religions, he explains, characteristically praise actions that are in accord with social instincts and behaviors and frown on actions that privilege the individual's private good over the good of the various groups of which he or she is a part. Neither Paul VI nor Wilson denies that members of our species have the biological capacity to choose to pursue their private good over the good of the group to which they belong. But Paul VI and Wilson both choose to call such choices sin because our natural flourishing to some degree depends on group selection, driven by social instinct, prevailing over individual selection. While they undoubtedly differ about many of the details, the effectual truth is that the pope and Wilson both think that each of us is fundamentally a social or relational being. For Wilson, organized religion has been pretty much "an expression of tribalism" and nothing more. For the pope, the Christian religion is much more. But he also thinks that the Christian religion, like every other legitimate religion, reflects and supports our social and relational duties as human beings.

Wilson further believes that the pope's encyclical overlooked yet another purpose for human sexual activity: Unlike females of other primate species, human females do not advertise estrus or "being in heat." As such, once bonded with a male, a human female can invite "continuous and frequent intercourse." The fertility-measuring method of Natural Family Planning that some Catholics practice, Wilson might have argued, can interfere with what nature intends for a husband and wife. In Wilson's mind, evolution adapted so that a woman could use sexual pleasure to entice the father of her children to stay around and help raise the children he has engendered. From an evolutionary point of view, it is clearly better for the parents of human children to stay bonded-sharing both parental 
responsibilities and sexual pleasure-until their offspring are fully raised. Reproduction and raising the young are equally indispensable functions of the social animal. Consequently, the social instinct of a woman, Wilson suggests, evolved so that she, unlike her male counterpart, would put her children first.

Sounding quite pro-family values, Wilson goes so far as to say that in the raising of children there is no reliable alternative to two "sexually and emotionally bonded mates." Even "in tightly-knit hunter-gather societies," human mothers cannot count on the broader community or tribe. From Wilson's evolutionary-informed point of view, the superiority of the twoparent heterosexual family with children is both natural and enduring. It may, as the saying goes, take a village to raise a child, but that village, Wilson adds, cannot take the place of the child's parents.

To use Wilson's word, women "sin" (and are unhappy) when they give and receive sexual pleasure as free individuals in the mistaken belief that they can remain "autonomous" and unguided by social instinct. The use of artificial contraception to rule out the possibility of having kids altogether, especially the casual use of artificial contraception outside of marriage, undermines the social or group cooperation that is, for Wilson, naturally responsible for the singular success of the most intelligent of the "eusocial" species. Ultimately, the pope and the professor agree that society, the family, and the human species all suffer when women are deceived by that mistaken judgment about who they naturally are. Catholics, with their appeal to natural law, find something of an ally in Wilson.

From a public-policy perspective, however, the big news is that Wilson's research shows social conservatism has more to do with what human beings can observe about themselves with their own eyes than it does with their blind adherence to some discredited, fundamentalist dogma. If Wilson were to think through the political implications of his scientific discoveries, his sociobiological concerns no doubt could move him to resist public policies that resolve the tension between the interests of the individual and the interests of the social community in a wholly individualistic direction.

\section{TOWARD A TRUE SCIENCE OF VIRTUE}

Today, post-modern-or non-Cartesian-conservative thinkers receive a good deal (if not plenty) of support from Darwinians in our effort to chasten the excesses of modern individualism. Playing a Lockean position 
off a Darwinian position does not capture the full truth about who we are as relational persons. But it is a start. I regularly make this point in my relatively countercultural blog, "Rightly Understood." One of that blog's purposes is to counter the libertarian excesses of the sophisticated technoenthusiasts who post at its host site, Big Think. Responding to a post in which I used E. O. Wilson's book to show that a true Darwinian cannot be a libertarian true believer, Larry Arnhart, the author of a long and penetrating chapter in this volume, wondered out loud whether I had converted to his Darwinian or evolutionary faith. I conclude this introduction by responding to Dr. Arnhart's gracious, but mistaken, speculation, to show where, in my view, a true science of modern virtue needs to go from here.

I begin by calling attention to the thought of Jonathan Haidt, a professor of psychology at the University of Virginia. His The Happiness Hypothesis argues that we human beings are simultaneously brilliant like the chimps and ultra-social like some insects. Unlike chimpanzees, who seem to have "the brains" but just cannot seem to get along with each other, our reason has the eusocial tendency to foster our attachments to groups and each other. Our heads, as Jefferson says, serve our hearts-or our social instinct or moral sense. As a result, our lives have to be consciously balanced. That is why sensible social conservatism must be moderately moderated by enlightened individualism. Haidt and Arnhart more or less agree that the modern philosophers who make the most sense are empiricists associated with the Scottish Enlightenment, that is, David Hume, Adam Smith, and to an extent, Thomas Jefferson. They also prefer the scientific Aristotle to the rational idealist Plato. Neo-Darwinians like Haidt and Arnhart believe the most scientific and reasonable philosophers admit that we are animals whose reason most properly serves our social instincts.

I am periodically accused of being a Heideggerian existentialist. Heidegger might have been the greatest philosopher of the twentieth century. But he was also, for a brief time at least, a Nazi-something for which he never publicly apologized. Ironically, the existentialist or, in a way, resolutely individualist philosopher Heidegger justified an ideology that thought of people as nothing more than parts of wholes called "races" or the "Fatherland." Heidegger eventually criticized Hitler's "biologism," by which he meant Hitler's false identification of our biological features with what we are simply. Hitler, Heidegger protested, did not see that deep down we are truly free individuals. (I note in passing that this might be a problem with many strains of Darwinism too.) 
Neo-Darwinians do not make it clear (because it would make them unpopular) that in their view anyone who does not believe that the science of biology can explain everything about who we are must be an existentialist. By this standard everyone from St. Paul to St. Augustine to St. Thomas Aquinas to contemporary American Evangelical Christians are Heideggerian existentialists. Descartes and Locke would also be Heideggerian existentialists, as would that rational defender of dignity and autonomy Immanuel Kant. Anyone who thinks we are in any way alienated or restless about who we are as purely biological beings would be a Heideggerian existentialist. My point is that, from this Darwinian view, Christians and Cartesians seem equally unscientific. They both introduce some alleged imaginary alien into the realm of biological nature and natural selection, the realm that houses members of every species, including our own.

St. Thomas Aquinas tried to reconcile Aristotelian naturalism with the Christian idea of the freely created, free, and irreducible human person. For someone with a Neo-Darwinian perspective, Aquinas displays both Darwinian and existentialist features-not surprisingly, when Dr. Arnhart chooses to invoke Thomas Aquinas he has to steer clear of all of Aquinas' references to our personal longing to know a personal God. For years now, I have argued that the great Thomist of (and for) the twentieth century was the American philosopher-novelist Walker Percy. Percy said that the scientific task of our time was to reconcile what is true about Anglo-American empiricism with what is true about Continental existentialism.

It should not, then, come as a big surprise that I think some Darwiniansespecially some Darwinian conservatives-are neither completely right nor completely wrong. I think the same thing about some Heideggerian existentialists, and some Cartesian and Lockean defenders of the free individual. Christians, Cartesians, Lockeans, and existentialists all defend the real existence of the free person who possesses a singular or "authentic" destiny. Still, a true science of modern virtue must recognize that, despite their enormous differences, Cartesian, Lockean, and Darwinian forms of science share certain basic features. One of these is their nominalism. Used as a way of defending the particular against the universal, nominalism is not all bad. But it does tend to reduce words to weapons and nothing more.

The Lockean nominalist uses words to secure the flourishing of the individual; the Darwinian nominalist uses words to promote natural selection and species survival. A true science of modern virtue should be 
able to acknowledge what is true about Cartesian, Lockean, and Darwinian science even as it goes on to show why none of these sciences can begin to explain the joy we experience when we scientifically communicate the truth about our world or that none of these sciences can capture the truth about who we personal, relational, truth-sharing, and loving human beings really are.

Peter Augustine Lawler 
